\title{
THE SIGNIFICANCE OF THE UREA CLEARANCE
}

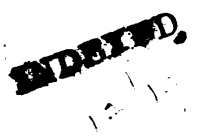

\author{
DONALD D. VAN SLYKE AND VINCENT P. DOLE \\ From the Hospital of the Rockefeller Institute for Medical Research, New York
}

BY

(RECEIVED FOR PUblication, JULy 18, 1949)

By the courtesy of Mr. H. Fairfield Smith we have had the privilege of examining in advance of publication his paper "Urea Clearance Tests." This paper appears to touch on three separate questions: (1) What does the clearance purport to measure? (2) What factors affect the clearance? (3) What is the diagnostic and prognostic significance of the clearance in renal disease? Inasmuch as the available data appear to have been only partially available to Mr. Smith, the writers venture to add the following comments on these questions.

\section{What Does Urea Clearance Measure ?}

The urea clearance measures the efficiency with which the kidneys remove urea from the blood stream, when due correction is made for the effects of low rates of urine flow. Studies on man and animals have shown that the urea clearance measures the rate of filtration of urea in the glomeruli minus the rate of urea reabsorption by the tubules (Van Slyke et al., 1934, 1935 ; Smith, 1937 ; Chasis and Smith, 1938 ; Shannon, 1936).

\section{Factors Affecting Clearance}

Like all physiological functions, the urea clearance varies under different physiological conditions, particularly those which affect the renal blood flow (Van Slyke et al., 1934, 1935) and the urine volume (Van Slyke, 1947; Möller et al., 1928 ; Dole, 1943). Consequently the clearance of a given subject may vary by as much as $\pm 20 \%$ of his average under the usual conditions of daily life (Möller et al., 1928). The variation of the clearance with urine flow has been studied (Van Slyke, 1947 ; Möller et al., 1928 ; Dole, 1943) and shown to be due to variations in tubular reabsorption of urea that are predictable by the simple diffusion laws (Dole, 1943). High protein diets have been shown to increase renal blood flow and urea clearance in dogs (Jolliffe et al., 1931), and partial protein starvation has been shown (Cope, 1933) to decrease the clearance in men, a finding which is confirmed by Mr. Smith's observations.
Variability is shown by other physiological functions, measurement of which is nevertheless of value in assessing clinical conditions: e.g., the metabolic rate, body temperature, and pulse rate vary with physical activity, excitement, etc. Such variability does not invalidate the measurement of these functions, or of the urea clearance, in assisting to estimate the condition of a patient.

Renal disease affects as a rule chiefly the rate of filtration, which decreases as glomerular destruction advances, although in advanced nephritis increased permeability of the tubules appears to add its effect by increasing urea reabsorption, particularly when urine volume is low (Van Slyke, 1947). Damage to the tubules by nephrotoxic substances (Richards, 1929 ; Lucké, 1946), or by renal ischaemia, such as occurs in severe and prolonged shock (Phillips et al., 1946; Van Slyke, 1948 ; Phillips et al., 1948) appears to make the tubules more permeable to back diffusion of urea into the blood, and lowers the clearance by increasing urea reabsorption. In all these conditions the urea clearance has been found of value in assisting the appraisal of the extent of renal damage, and the course of progress either towards recovery or fatal renal failure.

\section{The Diagnostic Significance of Urea Clearance in Renal Disease}

Neither the urea clearance, nor any other physiological measurement, should be asked to serve as the sole criterion to discriminate between health and disease. The clinician using such a test must evaluate the results in terms of all known causes of variation, physiological and pathological. As the increase of metabolic rate with muscular or digestive activity or excitement does not invalidate its use in the thyroid clinic, so the decrease of the urea clearance with protein starvation or shock (Phillips et al., 1946 ; Van Slyke, 1948) does not invalidate its utility in following the course of renal damage or disease, when proper allowance is made for the effect of extra-renal influences. 
Studies of a considerable number of cases of renal disease of different types, some of which were observed over periods of years, have led (Van Slyke et al., 1930) to the following conclusions :

"In acute hemorrhagic nephritis fall of the urea clearance to as low as $10 \%$ of normal was found not inconsistent with apparently complete recovery. . . . In all these cases which recovered or improved, however, the blood urea clearance began to rise within four months after the acute onset. ... Of the different features of (advanced renal) disease that were followed, the blood urea clearance proved to be the most closely related to the onset of final renal failure. The renal function, measured by the clearance, could apparently remain indefinitely at $10 \%$ of normal without uremia ; but when it fell to $5 \%$ uremia occurred, and was usually fatal. Exceptions to the immediately fatal outcome were found in acute cases, which can recover if the functional depression does not last too long, and occasionally a terminal case, in which functional fall was partly due to factors, such as desiccation, other than destruction of renal tissue. In such a case treatment, particularly saline and glucose injections, may both improve the general condition and somewhat increase the urea clearance, although the added lease of life appears to be at most a few months."
These observations have been confirmed and extended in subsequent studies continued to the present time in this clinic, and will be presented in a future publication.

\section{REFERENCES}

Chasis, H., and Smith, H. W. (1938). J. clin. Invest., 17, 347.

Cope, C. L. (1933). Ibid., 12, 567.

Dole, V. P. (1943). Amer. J. Physiol., 139, 504.

Jolliffe, N., and Smith, H. W. (1931). Ibid., 99, 101.

Luck', B. (1946). Mil. Surg., 99, 371.

Möller, E., McIntosh, J. F., and Van Slyke, D. D. (1928). J. clin. Invest., 6, 427, 485.

Phillips, R. A., and Hamilton, P. B. (1948). Amer. J. Physiol., 152 523.

- Dole, V. P., Hamilton, P. B., Emerson, K.. jun., Archibald, R. M. and Van Slyke, D. D. (1946). Ibid, 145, 314.

Richards, A. N. (1929). Trans. Ass. Amer. Phys., 44, 64.

Shannon, J. A. (1936). Amer. J. Physiol., 117, 206.

Smith, H. W. (1937). The Physiology of the Kidney. Oxford University Press. New York.

Van Slyke, D. D. (1947). J. clin. Invest., 26, 1159.

(1948). Ann. intern. Med., 28, 701.

Hiller, A., and Miller, B. F. (1935). Amer. J. Phvsiol., 113, 611. Rhoads, C. P., Hiller, A., and Alving, A. S. (1934a). Ibid., 109, 336.

(1934b). Ibid., 110, 387.

Stillman, E., Möller, E., Ehrich, W., McIntosh, J. F., Leiter, L. MacKay, E. M., Hannon, R. R., Moore, N. S., and Johnston, C (1930). Medicine, 8, 257. 